\title{
Habits of Mind Strategies for Enhancing Students' Math Problem Solving Skills
}

\author{
Mhmd Habibi', Dwi Lasia ${ }^{2}$, Mesi Oktafia ${ }^{3}$, Muhammad Ilham ${ }^{4}$ \\ 1,2,3Pendidikan Matematika, Institut Agama Islam Negeri Kerinci, Indonesia \\ ${ }^{4}$ Psikologi Profesi, Universitas Gadjah Mada, Indonesia \\ 1,4Researchers at JANUR ISTITUTE, Indonesia \\ 1mhmd habibi@yahoo.com,2dwiLasia2@gmail.com,3mesioktafia@gmail.com. \\ 4muhammadilham2020@mail.ugm.ac.id
}

\section{Article History: \\ Received : 12-07-2020 \\ Revised : :15-09-2020 \\ Accepted : 16-09-2020 \\ Online : 03-10-2020}

\section{Keyword:}

Habits of mind

Strategies;

Mathematics teaching

and learning;

Problem solving

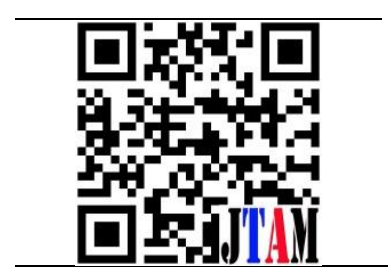

\section{ABSTRACT}

The objective of this research is to know the differences in mathematical problem solving skills between using mathematical habits of mind strategy with conventional learning. Methods that is used is quasi-experimental, with nonequivalent control group design. The subject of this study was a $7^{\text {th }}$ grade junior high school student with 56 number of people which were $12^{\text {th }}-13^{\text {th }}$ years old. with sampling techniques i.e. purposive sampling. Instruments that is used in this research is description test which was arranged based on mathematical problem solving skills material. Data analysis technique is with $\mathrm{N}$-Gain T-test. The result show that the significant $\mathrm{N}$-Gain score obtained is 0.008 . The $\mathrm{N}$-Gain score is smaller than ( $a=0.05$ ), which means that there is a significant difference in the increase in mathematical problem solving abilities toward participant student who use mathematical habits of mind strategies with those using conventional learning. statistically proven habits of mind strategy that influences problem solving can be one of the practitioners' choices in teaching mathematics in basic education.

\begin{tabular}{cc}
\hline dof $\$$ Crossref & (c) () () () \\
https://doi.org/10.31764/itam.v4i2.2590 & This is an open access article under the CC-BY-SA license \\
\hline
\end{tabular}

\section{A. INTRODUCTION}

Education is an activity undertaken to achieve a certain goal and an activity that is aware of the goals to be achieved in an educational institution (Đurišić \& Bunijevac, 2017). Education aims to develop the ability of students so that students can develop themselves towards the community and the surrounding environment (Đurišić \& Bunijevac, 2017; M. Habibi, Darhim, \& Turmudi, 2018; Tiara et al., 2020). Through education, it is expected that humans can develop the potential he has in both the community or the surrounding environment and with the existence of human education can achieve the ideals desired and it is hoped that through education it can shape people who are pious and have faith in God. 
There are various subjects given to students. One of them is mathematics. Mathematics is one of the compulsory subjects in every educational institution (Schneider \& Artelt, 2010). Mathematics is a science needed in nowadays and in the future (Habibi, Darhim, and Turmudi, 2019). So mathematics needs to be given to the students starting from the elementary to the middle level even to the university. One of the goals of learning mathematics is that students can solve problems that include the ability to understand problems, design models, solve models and interpret the solutions obtained (Zakaria, 2010).

Mathematical learning aims to shape students' thinking abilities, including encouraging students to get used to thinking or often known as mathematical habits of mind (Cuoco, Paul Goldenberg, \& Mark, 1996; Masni, 2017). The purpose of learning mathematics is to develop the ability to think critically, logically, systematically, thoroughly, effectively, and efficiently in solving the problems being faced (Schneider \& Artelt, 2010). Mathematics learning has a very important role in education because mathematics is one of the compulsory lessons starting from the elementary level to the secondary level even to the university which aims to have students' mathematical abilities especially the ability to solve mathematical problems, so students are expected to be able to solve the problem being faced.

According to Polya problem solving is an attempt to find a way out of difficulties in achieving goals that cannot be achieved immediately (Booker \& Windsor, 2010). Problemsolving ability is a focal point in learning mathematics to improve students' problem-solving abilities so it is necessary to understand the problem, design models, solve models and interpret the solutions obtained. Problem-solving skills are very important and need to be developed for students in learning mathematics because with the ability to solve problems owned by students are expected to be able to direct and assist students in solving problems encountered. According to Polya the indicators of problem-solving in are (1) understanding the problem; (2) planning a problem-solving model; (3) implementing the problem-solving model; (4) see (check) the answer again whether it is correct, during checking the solution to the problem must be considered (Jacobbe \& Millman, 2009; Polya, 1945).

However, the reality that occurs in the school environment shows that students have not been able to solve problems properly according to mathematical problem-solving indicators and have not been able to use their problem-solving abilities in solving problems. This can be seen from the results of observations and initial tests of mathematical problem-solving skills at junior high school. This is also supported by the results of research by Delyana (2015) which shows that the ability of students to solve problems has not been optimally developed, students are less able to solve problems related to the material that has been learned, even though the teacher has tried to guide students to solve them.

The results of the initial test of problem-solving ability were given to all students in $7^{\text {th }}$ grade of junior high school, which amounted to 56 students, only 8 students whose scores reached 75 and were included in the high category while other students rated below 75 and were still in the low category. From the results of the test the problem-solving ability shows that the ability to solve mathematical problems of students is still relatively low, so efforts are needed to be able to improve students' mathematical problem-solving abilities. The low ability of students' mathematical problem solving can be caused by a lack of mathematical 
thinking habits. One of the most important things that must be considered by the teacher in the learning process is the strategy or method used in the learning process.

Learning mathematics is generally centered on the teacher, formal, rigid, and less fun and boring (Habibi \& Mhmd, 2014), students generally only receive knowledge transfer from the teacher, and the teacher only conveys scientific information without wanting to involve students actively and generatively in the learning process (Randi, Ahmad, \& Mhmd, 2019). The teacher's role is very important for students and must be able to generate interest to actively follow the lessons and be directly involved in solving the proposed problem, guiding students step by step so that students are able to find and solve the problems encountered. Because it is necessary to properly implement a strategy or method that is suitable so that students can be actively involved in the learning process, familiarize and civilize students to think mathematics with efforts to achieve the objectives of learning and improve students' mathematical problem-solving abilities (Habibi, 2014; Randi et al. 2019).

One suitable strategy that can improve students' mathematical problem-solving abilities is the mathematical habits of mind strategy. What is meant by this mathematical habits of mind strategy is a strategy used to develop mathematical thinking and can develop problemsolving abilities through habituation and acculturation that is done routinely and continuously (Mielicki \& Wiley, 2016). Mathematical habits of mind or commonly known as mathematical thinking habits are introduced to be able to help students in thinking mathematics itself (Mussardo, 2019). So Habits of mind are a habit that if done routinely and continues to stammer it will become a habit that stick on students themselves.

Milman and Jacobbe (Jacobbe \& Milman, 2009)say that mathematical habits of mind consist of five components, namely: 1) exploring mathematical ideas, 2) reflecting the suitability and correctness of answers, 3) generalizing, 4) formulating questions, and 5) constructing samples. The five components of a mathematical habits of mind strategy if done continuously, routinely and consistently will have the potential at a good level of mathematical problem solving ability. This is supported by one of Jacobbe's researches that shows that the use of mathematical habits of mind strategies involving the five components will be able to improve the ability to solve mathematical problems.

For this reason, it is necessary to apply mathematical habits of mind with an effort to improve the ability to solve mathematical problems. If students have mathematical habits of mind, students have the ability to endure everything. Based on the above problems, the researcher is interested in conducting a study entitled habits of mind strategies in improving students' mathematical problem solving abilities.

\section{B. METHODS}

This research is a quantitative study with quasi-experimental methods or often called quasi-experiments, with the design used is non-equivalent control group design. The population used in this study was the entire of $7^{\text {th }}$ grade junior high school students which were $12^{\text {th }}-13^{\text {th }}$ years old. With the sample used experiment group and controlgroup.. Both groups were subjected to a homogeneity test prior to intervention, and its result showed that both groups were homogeneous. It In this study, the sampling technique that used is purposive sampling. 
The instrument used in this study was a test of problem-solving ability in the form of a description / essay. The instrument consists 20 problems which were arranged based on five indicators of mathematical habits of mind by Milman and Jacobbe and those scored based on the scoring rubric. Before this test is given to the sample, first this test is tested for normality, reliability, difficulty index and different power to see the feasibility of the test questions that will be used to determine the level of students' mathematical problem solving abilities. This research was conducted during ten meetings of eight learning process meetings, and each meeting was added once for the assessment of the pre-test and post-test in the experimental and control classes.

The first data analysis technique used is the normality test this test is done to see the hypothesis that is normally distributed, then the homogeneity variance test is performed to see similarities between groups or homogeneous. Then the N-Gain test (pre-test and post-test) is performed to see the improvement of problem solving abilities. Then the T-test is performed to see the difference in students' mathematical problem solving abilities. The $\mathrm{N}$ Gain calculation uses the help of the SPPS software. Furthermore, a T-test is performed to determine the difference in the increase in the experimental class and the control class after the treatment.

\section{RESULT AND DISCUSSION}

This research was conducted in the experimental class and the control class for 10 (ten) meetings and added 2 (two) meetings for the pre-test and post-test assessments. The pre-test assessment is done before the treatment to see the students 'initial abilities, while the posttest is done after the treatment to see the students' abilities after the treatment given by the teacher. The average pre-test score obtained by the experimental class was 62.7 and the control class obtained an average value of 63 while the post-test average value obtained by the experimental class was 82 and the dick class obtained an average value of 73 .

The pre-test and post-test data values were tested for normality first to see the data that were normally distributed using SPSS 16. The following results of the calculation of normality tests used the Shapiro Wilk test in Table 2.

Table 2. The Result of Normality Test (pre-test and post-test)

\begin{tabular}{cccccc}
\hline \multirow{2}{*}{ Groups } & \multicolumn{4}{c}{ Shapiro Wilk } \\
\cline { 3 - 6 } & & Sig & Statistic & Df & Sig \\
\hline \multirow{2}{*}{ Pre-test } & Experiment & .180 & .942 & 18 & .153 \\
\cline { 1 - 5 } Post- & control & .200 & .949 & 18 & .416 \\
test & Experiment & .120 & .952 & 18 & .458 \\
\hline
\end{tabular}

Table 1 shows that the pre-test value of the experimental class after being tested for normality is 0.153 and the control class is 0.416 , the pre-test value of the experimental class and the control class is greater than $(\alpha=0.05)$ which means that the pre-test value of the experimental class and the control class is normally distributed. While the post-test value of the experimental class after the normality test is 0.458 and the control class is 0.747 , this shows that the post-test value of the experimental class and the control class is greater than 
$(\alpha=0.05)$ which means that the post-test data is normally distributed. After the normality test is carried out, then the variance homogeneity test is performed to see the homogeneous data, the homogeneity test calculation uses a statistical levene test with the help of the SPSS program, following the results of the variance homogeneity test calculation Table 2.

Table 2. The Result of homogenity of Varian (pre-test and post-test)

\begin{tabular}{llcccc}
\hline & Levene statistic & Df1 & Df2 & Sig \\
\hline \multirow{5}{*}{ Pre-test } & .119 & 1 & 34 & .732 \\
& $\begin{array}{l}\text { Based on mean } \\
\text { Based on the median }\end{array}$ & .057 & 1 & 34 & .813 \\
& $\begin{array}{l}\text { Based on the median with } \\
\text { adjusted df }\end{array}$ & .057 & 1 & 33,346 & .813 \\
Based on trimmed on mean & 0.99 & 1 & 34 & .755 \\
Based on mean & .572 & 1 & 34 & .455 \\
Based on the median & .553 & 1 & 34 & .462 \\
Post-test & $\begin{array}{l}\text { Based on the median with } \\
\text { adjusted df }\end{array}$ & .553 & 1 & 31,338 & .463 \\
& Based on trimmed on mean & .551 & 1 & 34 & .463 \\
\hline
\end{tabular}

Based on Table 2, after the variance homogeneity test was carried out in the experimental class and the control class obtained homogeneous or equal data, which means that it can carry out further tests namely the N-Gain test and proceed with the N-Gain T test. The results of the $\mathrm{N}$-Gain test after calculations using SPSS are as follows Table 3.

Table 3. The Result of N-Gain Test

\begin{tabular}{ccc}
\hline & experiment & control \\
\hline $\bar{X}$-pre & 62,7 & 63 \\
$\bar{X}$-post & 82 & 73 \\
N- Gain Score & 0,5144 & 0,1710 \\
Category & middle & low \\
\hline
\end{tabular}

Based on Table 3, the N-Gain value of the experimental class was 0.5144 and the control class was 0.1710 , which means that the experimental class and the control class both experienced an increase, but in the experimental class, the ability to solve mathematical problem solving was in the medium category. However in the control class experienced an increase in mathematical problem solving abilities in the low category. Then the t-test is performed to see the difference in the increase that occurs in the experimental class and the control class, Table 4.

Table 4. The Result of T- Test of N-Gain Independent samples test

\begin{tabular}{|c|c|c|c|c|c|c|c|c|c|c|}
\hline \multicolumn{6}{|c|}{ Levene's test of equality of variances } & \multicolumn{5}{|c|}{ T-test for equality of means } \\
\hline & & \multirow[t]{2}{*}{$\mathrm{F}$} & \multirow[t]{2}{*}{ Sig } & \multirow[t]{2}{*}{$\mathrm{t}$} & \multirow[t]{2}{*}{ Df } & \multirow[t]{2}{*}{$\begin{array}{l}\text { Sig. } \\
\text { (2tail } \\
\text { ed) }\end{array}$} & \multirow[t]{2}{*}{$\begin{array}{c}\text { Mean } \\
\text { differe } \\
\text { nce }\end{array}$} & \multirow{2}{*}{$\begin{array}{c}\text { Std. } \\
\text { Error } \\
\text { differen } \\
\text { ce }\end{array}$} & \multicolumn{2}{|c|}{$\begin{array}{c}\text { 95\% confidence } \\
\text { interval of the } \\
\text { difference }\end{array}$} \\
\hline & & & & & & & & & lower & upper \\
\hline \multirow{2}{*}{$\begin{array}{l}\text { N-Gain } \\
\text { score }\end{array}$} & $\begin{array}{l}\text { Equal variances } \\
\text { assumed }\end{array}$ & .303 & $\begin{array}{l}.58 \\
6\end{array}$ & 2.8 & 34 & .008 & .343 & .120 & .097 & .589 \\
\hline & $\begin{array}{l}\text { Equal variances } \\
\text { not assumed }\end{array}$ & & & 2.5 & 32.3 & .008 & .343 & .120 & .097 & .589 \\
\hline
\end{tabular}


Based on Table 4, the T-test results show that the significant n-gain score obtained is 0.008. The n-gain score is smaller than $(\alpha=0.05)$, which means that there is a significant difference in the increase in mathematical problem solving abilities towards participants students who use mathematical habits of mind strategies with those using conventional learning. This proves that learning using the habits of mind strategy is better than before with a $95 \%$ confidence level.

The purpose of applying learning with the habits of mind strategy is to determine the level of mathematical problem solving ability. At the beginning of the learning process the teacher first introduces mathematical habits of mind strategies that will be used during the learning process. After the teacher introduces mathematical habits of mind strategy then the teacher distributes students in several groups to start learning. The teacher gives appreciation by reminding students about the material related to calculating the mean, median and mode of a data. Then the teacher provides motivation so that students are interested in learning and convey the objectives to be achieved from learning (M. Habibi et al., 2018).

The core activity of learning begins with questions and answers relating to learning material in order that the teacher can know the initial abilities possessed by students (M. Habibi et al., 2018) relating to the mean, median and mode material. Next the teacher gives 1 example problem about the mean, median and mode to be discussed with peers. In the initial stages the teacher directs and helps students to complete the example problems in accordance with mathematical habits of mind strategy steps and in accordance with indicators of problem solving in accordance with what is explained by the teacher with his peers.

The first stage that students do is explore mathematical ideas at this stage the teacher tells students to explore mathematical ideas by describing all the data obtained from the questions, what data is needed to solve the problem (Silver, 1997). Students work together with their peers to understand the problem and mention what data is obtained and design a formula that is suitable for solving the problem.

In the second stage the teacher directs students to solve the problem with the formula that has been found, and students are also directed to find another formula or new to solve the problem. Furthermore, the teacher directs students and their peers to look for something new and relate it to existing problems (generalization), then look for ways of calculation and solve the new problem (Randi et al., 2019). Finally students are invited to formulate questions, construct examples and encourage students to repeat the process (Pajares \& Miller, 1994). At this stage, the teacher gives students the opportunity to ask questions about examples of questions that have been given about what are not understood, and students are directed to make examples of these problems (Flavell, 1979; Rott, 2020).

\section{CONCLUSION AND SUGGESTIONS}

Based on the results of research on mathematical habits of mind strategies in improving students 'mathematical problem solving abilities, it is concluded that: the process of applying mathematical habits of mind strategy, is able to have a significant impact on improving students' problem solving abilities through learning steps of habits of mind which is measurable and well planned. 
Stages in the form of giving appreciation and motivation before learning begins; question and answer to students aiming at the teacher knowing students' initial abilities about the material to be discussed; and the teacher's explanation that always pays attention to the flexibility of students in exploring mathematical ideas proved to be able to provide a good understanding of students in their efforts to solve mathematical problems. Therefore, a statistically proven habits of mind strategy that influences problem solving can be one of the practitioners' choices in teaching mathematics in basic education. As a suggestion for further researchers, it is expected to be able to use at the same time test the habits of mind strategy on a variety of mathematical material that is known to be difficult and complicated.

\section{REFERENCES}

Booker, G., \& Windsor, W. (2010). Developing Algebraic Thinking: Using Problem-Solving to Build from Number and Geometry in The Primary School to The Ideas that Underpin Algebra in High School and Beyond. Procedia - Social and Behavioral Sciences, 8, 411-419. https://doi.org/10.1016/j.sbspro.2010.12.057

Cuoco, A., Paul Goldenberg, E., \& Mark, J. (1996). Habits of mind: An organizing principle for mathematics curricula. Journal of Mathematical Behavior. https://doi.org/10.1016/S07323123(96)90023-1

Delyana, H. (2015). Peningkatan Kemampuan Pemecahan Masalah Matematika Siswa Kelas VII Melalui Penerapan Pendekatan Open Ended. Lemma.

Đurišić, M., \& Bunijevac, M. (2017). Parental involvement as a important factor for successful education. Center for Educational Policy Studies Journal, 7(3), 137-153.

Flavell, J. (1979). Theories of Learning in Educational Psychology. American Psychologist.

Habibi, Mhmd. (2014). Pengembangan Modul Pecahan Berbasis Konstruktivisme Dengan Sisipan Karikatur Untuk Kelas IV Sekolah Dasar. Proseding Seminar Nasional Pendidikan Matematika., 2748. Bandung: UNINUS.

Habibi, M., Darhim, \& Turmudi. (2018). Self-Determination in Mathematics Learning Process by Using Generative Multi - Representation Learning (GMRL) Model. Journal of Physics: Conference Series, 1097(1). https://doi.org/10.1088/1742-6596/1097/1/012155

Habibi, M., Darhim, D., \& Turmudi, T. (2019). Pengembangan Bahan Ajar dan LKS Berbasis Generative Multi-Representation Learning (GMRL) untuk Peningkatan Kemampuan Berpikir Aljabar. Jurnal Cendekia : Jurnal Pendidikan Matematika. https://doi.org/10.31004/cendekia.v3i2.115

Jacobbe, T., \& Millman, R. S. (2009). Mathematical Habits of the Mind for Preservice Teachers. School Science and Mathematics. https://doi.org/10.1111/j.1949-8594.2009.tb18094.x

Masni, E. D. (2017). Asosiasi Kemampuan Pemecahan Masalah Dan Mathematical Habits of Mind Siswa Smp. Jurnal Penelitian Pendidikan INSANI, 20(2013), 38-44.

Mielicki, M. K., \& Wiley, J. (2016). Alternative representations for algebraic problem solving: When are graphs better than equations? Journal of Problem Solving, 9(1). https://doi.org/10.7771/19326246.1181

Mussardo, G. (2019). mathematical habits of mind. Statistical Field Theor, 53(9), 1689-1699. https://doi.org/10.1017/CB09781107415324.004

Pajares, F., \& Miller, M. D. (1994). Role of Self-Efficacy and Self-Concept Beliefs in Mathematical Problem Solving: A Path Analysis. Journal of Educational Psychology, 86(2), 193-203. https://doi.org/10.1037/0022-0663.86.2.193

Polya, G. (1945). Polya ' s Problem Solving Techniques. In How To Solve It.

Randi, P., Ahmad, F., \& Mhmd, H. (2019). The Impact of Cognitive Conflict Based Learning Tools on Students Mathematical Problem Solving Ability. International Journal of Educational Dynamics, 1(2), 209-218. https://doi.org/doi.org/10.24036/ijeds.v2i1.247

Rott, B. (2020). Problem solving in mathematics education. Research in Mathematics Education, 1-4. https://doi.org/10.1080/14794802.2020.1731577

Schneider, W., \& Artelt, C. (2010). Metacognition and mathematics education. ZDM - International 
Journal on Mathematics Education, 42(2), 149-161. https://doi.org/10.1007/s11858-010-0240-2 Silver, E. A. (1997). Fostering creativity through instruction rich in mathematical problem solving and problem posing. ZDM - International Journal on Mathematics Education, 29, 75-80. https://doi.org/10.1007/s11858-997-0003-x

Tiara, Nofrianti, L., Habibi, M., Musdizal, Putra, A., Angela, L., ... Lardiman. (2020). Utilization of environment as a learning media or natural science study in junior high schools. International Journal of Scientific and Technology Research, 9(2).

Zakaria. (2010). The Effects of Cooperative Learning on Students' Mathematics Achievement and Attitude towards Mathematics. Journal of Social Sciences, 6(2), 272-275. https://doi.org/10.3844/jssp.2010.272.275 